\title{
Effect of re-mating intervals on growth and reproductive performance of rabbits
}

\author{
BK Saha' ${ }^{1}$ MB Sarker ${ }^{1}$, MH Alam ${ }^{1}$, ME Kabir ${ }^{2}$, MR Amin ${ }^{1}$, M Moniruzzaman ${ }^{1}$ \\ ${ }^{1}$ Department of Animal Science, Bangladesh Agricultural University, Mymensingh 2202; ${ }^{2}$ Department of General \\ Animal Science and Animal Nutrition, Patuakhali Science and Technology University, Dumki, Patuakhali 8602, \\ Bangladesh
}

\begin{abstract}
The aim of this study was to know the effects of postpartum re-mating intervals on reproductive performances of does and growth of kits. Fifteen female New Zealand White crossbred rabbits were divided into three groups of equal numbers. They were re-mated within 24 hours, at 10 days and 28 days postpartum. Animals were individually caged in cells measuring $2^{\prime} \times 2^{\prime} \times 2^{\prime}$. Does were kept under natural lighting. Plastic nest boxes were supplied to does 3-4 days before parturition. They were reared up to four generation. Litter weight at birth was significantly $(p<0.05)$ higher at 10 days postpartum than within 24 hours and at 28 days postpartum intervals. Higher growth rate was observed in 10 days postpartum group comparing to other re-mating groups. Milk yield of the dams were significantly $(p<0.05)$ higher when dam re-mated at 10 days postpartum than those re-mated within 24 hours after parturition. Conception rate, gestation length of does, litter size at birth and weaning, litter weight at weaning, doe weight at mating, kidding, weaning and kid mortality did not differ significantly among the groups. Rabbit does re-mated at 10 days postpartum show maximum litter weight at birth, growth rate of kits and milk yield of dam.
\end{abstract}

Key words: Growth, rabbit, reproduction, re-mating intervals

Bangladesh Animal Husbandry Association. All rights reserved. $\quad$ Bang. J. Anim. Sci. 2011. 42 (2): 143-147

\section{Introduction}

Rearing of rabbit has an economic importance in developing countries mainly for meat production (FAO 1996). Resource poor farmers are interested to this enterprise, as it involves low capital and labor investment. Being herbivores, rabbits do not compete with humans for their food. In Bangladesh, rabbit enterprise has got considerable attention lately, as climatic condition, commercial factors and religious, social and technological aspects corroborate its rearing for meat production. In developing countries rabbit production is a potential practice to overcome the crisis of animal protein (Owen 1981). In addition, rabbit skin can be used in the production of toys, craft work and garments and also in cottage industries (Leach and Barret 1984), and their manure is a useful fertilizer for crops and gardens. The advantage of raising rabbits for human consumption rests on their potential biological efficiency. However, the gap between biological potential and practical

*Corresponding Author: monir.as@bau.edu.bd achievement is still wide in terms of reproductive performance.

The interaction between re-mating interval and the reproductive performance has a significant effect on several traits such as conception rate, gestation length, litter size, weaning weight, litter weight, body weight of doe, mortality, growth rate and milk production of dams (Smith and Somade 1994). McNitt et al. (1996) reported that does are fertile $24 \mathrm{~h}$ after kidding and can be rebred at this time. It was shown by Cheeke (1983) that rabbits could be mated 24 hours after kidding since rabbits are induced ovulators. If early re-mating is successful, there is a possibility of increasing reproductive rate. However, a short re-mating intervals after kidding may not allow for adequate recovery of the body reserve of the does. As a consequence there may be a decrease of fertility, milk production, litter weight at weaning and an increase in kit mortality. Moreover, the practice of rebreeding $24 \mathrm{~h}$ (1day) 
after kidding was condemned by animal welfare group (Harkness, 1988). In the United States, majority of producers re-breed at 14 days or 35 days post-partum (Harris et al. 1982). Re-mating interval most commonly adopted by Spanish farmers is 11 days post-partum (Rafel, 2001). In the United Kingdom, does in large scale production units were usually re-mated 14 to 21 days after kidding (Partridge et al. 1984). One of the problems in the management of domestic rabbits is the selection and adoption of a suitable time of mating after parturition especially under an intensive system of production. A suitable remating interval of rabbits may offer an opportunity for increasing the output of rabbit farming. Therefore, the present experiment was designed to investigate the effects of postpartum re-mating intervals on reproductive performance of does and growth of kits.

\section{Materials and Methods}

The research was carried out at the Goat, Sheep and Horse Farm under the department of Animal Science, Bangladesh Agricultural University, Mymensingh with fifteen New Zealand White crossbred rabbit does and nine bucks aged about 2 months. Does were divided into three groups, having equal number ( 5 does and 3 bucks in each group) of does and bucks in each group. The grouping was done based on three postpartum remating time periods. The does are re-mated within 24 hours, at 10 days and 28 days after parturition. Animals were individually caged in cells measuring $2^{\prime} \times 2^{\prime} \times 2^{\prime}$. Does were kept under natural lighting throughout the experiment. Plastic nest boxes were supplied to does 3-4 days before parturition. Rabbits were given unrestricted access to natural grass and drinking water. The natural grass was supplied at $10 \mathrm{am}$ and $4 \mathrm{pm}$. An amount of $100 \mathrm{~g}$ of mixture containing $2340 \mathrm{kcal} \mathrm{ME} / \mathrm{kg}$ and $17 \%$ $\mathrm{CP}$ was supplied to rabbits. The concentration ration was supplied at 10 am 3 pm. Kits were allowed for suckling 3 times a day up to weaning at 28-30 days. Mating was done in the morning using tested adult bucks. Conception rate, gestation length, milk production, litter size, growth rate, body weight of does and kits mortality were recorded. The data generated from this experiment were analyzed using "SAS 9.1.3" statistical program to compute the analysis of variance (ANOVA) for CRD. The means were compared with Duncan's Multiple Range Test (DMRT).

\section{Results and Discussion}

In the present study, conception rates were 86.4, 80.0 and 93.2 percent in in three groups of remating intervals i.e. within 24 hours, at 10 days and 28 days after parturition, respectively (Table $1)$. These rates did not differ significantly $(p>0.05)$ among the groups. Iyeghe-Erakpotobor et al. (2005) reported $85 \%$ conception rate while remated 14 days, $65 \%$ and $50 \%$ for re-mating at 21 and 28 days, respectively. Mendez et al. (1986) reported that conception rate was generally higher in does re-mated at 25 days than 1 day or 9 days re-mated rabbits. Awojobi et al. (2005) showed that conception rate was highest in the 21-28 days group (98.8\%) and lowest in the 10-20 days group $(68.4 \%)$. They found that re-mating at 10-20 days after parturition is the time of peak of lactation and therefore partitioning of low level of nutrients for high milk yield, embryonic survival and maintenance may result the lower conception rate. However, the conception rate did not differ significantly among these re-mated does although the reason is not understood in the present study.

Gestation length did not differ significantly ( $p>0.05$ ) among the three postpartum re-mating interval groups (Table 1 ). A similar result was found by Oguike et al. (2008) who worked with 27 primiparous Dutch and Chinchilla crosses, comprising re-mating intervals at 3, 4 and 5 weeks.

There were no significant $(p>0.05)$ differences in litter size between different treatment groups (Table 1 ). This result agrees with the finding of Martin and Donal (1976) and Iyeghe-Erakpotobor et al. (2005). Litter size at weaning also did not differ significantly among the different treatment groups (Table 1 ). 


\section{Effect of re- mating intervals on performance of rabbit}

Table 1. Effects of different postpartum re-mating intervals on reproductive performances of does

\begin{tabular}{lccc}
\hline & \multicolumn{3}{c}{ Postpartum re-mating period } \\
\cline { 2 - 4 } Parameters & $\begin{array}{c}\text { After parturition } \\
\text { (within 24 } \\
\text { hours) }\end{array}$ & $\begin{array}{c}\text { 10 days } \\
\text { postpartum }\end{array}$ & $\begin{array}{c}\text { After weaning } \\
\text { (28 days) }\end{array}$ \\
\hline Conception rate (\%) & $86.40 \pm 18.62$ & $80 \pm 27.38$ & $93.20 \pm 15.20$ \\
Gestation length (days) & $30.53 \pm 0.51$ & $30.35 \pm 0.35$ & $30.47 \pm 0.51$ \\
Litter size at birth & $3.60 \pm 0.82$ & $3.80 \pm 0.97$ & $3.50 \pm 0.71$ \\
Litter size at weaning & $3.20 \pm 0.57$ & $3.30 \pm 0.91$ & $3.30 \pm 0.90$ \\
\hline
\end{tabular}

Litter weight at birth significantly $(p<0.05)$ varied in different postpartum re-mating intervals (Table 2). Litter weight at birth of kits was higher in does re-mated at 10 days postpartum comparing those re-mated within 24 hours and 10 days postpartum. This may be due to higher milk intake of kits, because of dam get enough time to retrieve their body condition after parturition. On the other hand, Iyeghe-Erakpotober et al. (2005) reported that birth weights of kit appeared to be unaffected by reducing the re-mating interval after parturition.

Average litter weight at weaning did not differ in the different mating intervals (Table 2). IyegheErakpotober et al. (2005) reported that litter weight did not differ significantly while rebred at 14, 21 and 28 days postpartum.

Table 2. Effects of different postpartum re-mating intervals on litter weight at birth and weaning

\begin{tabular}{lcccc}
\hline & \multicolumn{3}{c}{ Postpartum re-mating period } & \\
\cline { 2 - 4 } Parameters & $\begin{array}{c}\text { After parturition } \\
\text { (within } 24 \\
\text { hours) }\end{array}$ & $\begin{array}{c}10 \text { days } \\
\text { postpartum }\end{array}$ & $\begin{array}{c}\text { After weaning } \\
(28 \text { days) }\end{array}$ & $\begin{array}{c}\text { Sig. } \\
\text { level }\end{array}$ \\
\hline $\begin{array}{l}\text { Litter weight }(\mathrm{g}) \\
\text { at birth }\end{array}$ & $37.50^{\mathrm{a} b} \pm 7.82$ & $42.50^{\mathrm{a}} \pm 2.12$ & $32.62^{\mathrm{b}} \pm 8.21$ & * \\
$\begin{array}{l}\text { Weaning } \\
\text { weight }(\mathrm{g})\end{array}$ & $206.08 \pm 54.05$ & $255.34 \pm 64.34$ & $237.72 \pm 58.33$ & NS \\
\hline
\end{tabular}

Means with uncommon superscripts at the same row differed significantly; $*, p<0.05 ; N S$, non-significant $(p>0.05)$
The body weight of does was not significantly different $(p>0.05)$ at mating, kidding and at weaning (Table 3). Similar results were observed by Oguike et al. (2008) conducted an experiment on rabbits re-mated at 3 weeks, 4 weeks and 5 weeks postpartum intervals. Nicodemus et al. (2002) also reported that there was no significant effect on body weight of rabbit does at different mating intervals.

Table 3. Effects of postpartum re-mating intervals on weight of does

\begin{tabular}{lccc}
\hline \multirow{2}{*}{ Period of } & \multicolumn{3}{c}{ Weight of does $(\mathrm{kg})$} \\
\cline { 2 - 4 } weighing & $\begin{array}{c}\text { After parturition } \\
\text { (within 24 hours) }\end{array}$ & $\begin{array}{c}\text { 10 days } \\
\text { postpartum }\end{array}$ & $\begin{array}{c}\text { After weaning } \\
\text { (28 days) }\end{array}$ \\
\hline At mating & $1.62 \pm 0.09$ & $1.68 \pm 0.09$ & $1.70 \pm 0.05$ \\
At kidding & $1.64 \pm 0.07$ & $1.64 \pm 0.09$ & $1.66 \pm 0.06$ \\
At weaning & $1.62 \pm 0.04$ & $1.64 \pm 0.08$ & $1.67 \pm 0.07$ \\
\hline
\end{tabular}

The growth rates of kits of three postpartum remating intervals are shown in Table 4 . There was no significant $(p>0.05)$ difference in growth rate at the $1^{\text {st }}$ parturition in three re-mating interval groups. In the $2^{\text {nd }}$ parturition the live weight gain was significantly higher in kits of 10 days postpartum re-mating group than immediately after parturition. This may be due to higher individual milk intake of kits in 10 days postpartum re-mating group than the group re-mated immediately after parturition. In the $3^{\text {rd }}$ parturition, significant difference was not found in live weight gain between 10 days postpartum and after weaning remating group but significantly differed with group re-mated immediately after parturition. Higher milk production of the dam and early habit of green grass and concentrate feeding of kits may result significantly higher growth rate in 10 days postpartum re-mating interval (Table 4). This result was supported by Partridge et al. (1984) and Lebas et al. (1986) who reported that the growth rate of kits increased when does were rebred at 7 days interval comparing to 21 and 28 days postpartum re-mating. 
Saha et al. (2013) Bang. J. Anim. Sci. 42 (2): 143- 147

Table 4. Effects of different postpartum re-mating intervals on growth rate of kits.

\begin{tabular}{|c|c|c|c|c|}
\hline \multirow[b]{2}{*}{$\begin{array}{l}\text { Post-partum } \\
\text { time }\end{array}$} & \multicolumn{3}{|c|}{ Growth of Kits } & \multirow[b]{2}{*}{$\begin{array}{l}\text { Sig. } \\
\text { level }\end{array}$} \\
\hline & $\begin{array}{c}\text { After } \\
\text { parturition } \\
\text { (within } 24 \text { h) }\end{array}$ & $\begin{array}{c}10 \text { days } \\
\text { postpartum }\end{array}$ & $\begin{array}{l}\text { After weaning } \\
\qquad(28 d)\end{array}$ & \\
\hline $1^{\text {st }}$ parturition & $4.42 \pm 1.43$ & $4.45 \pm 1.30$ & $4.06 \pm 1.23$ & NS \\
\hline $2^{\text {nd }}$ parturition & $5.00^{b} \pm 1.22$ & $8.08^{a} \pm 0.86$ & $7.60^{\mathrm{ab}} \pm 3.32$ & * \\
\hline $3^{\text {rd }}$ parturition & $8.46^{b} \pm 1.11$ & $18.49 \mathrm{a} \pm 1.98$ & $14.26^{a} \pm 5.45$ & *夫 \\
\hline $4^{\text {nd }}$ parturition & $9.81 \pm \pm 1.78$ & $20.11^{\mathrm{a}} \pm 2.07$ & $15.63^{b} \pm 4.19$ & ** \\
\hline
\end{tabular}

Means with uncommon superscripts at the same row differ significantly; $*, p<0.05 ; * *, p<0.01$; NS, nonsignificant $(p>0.05)$

Mortality of kits $(40 \%, 50 \%$ and $20 \%$ of does remated within 24 hours after purturtion, at 10 days and 28 days after parturition, respectively) did not differ significantly $(p>0.05)$ among the three postpartum re-mating intervals. Similar results showed by Partridge et al. (1984) in which least mortality $(30 \%)$ was observed in does re-bred 1 day postpartum and $42 \%, 43 \%$ and $47 \%$ of does rebred 7, 14 and 21 days postpartum respectively. Although lyeghe-Erakpotobor et al. (2005) reported higher mortality for the 21 and 28 days postpartum re-mating of does compared to 14 days postpartum.

Daily milk production of the dam was significantly higher when dams were re-mated 10 days postpartum $(28.70 \mathrm{~g} / \mathrm{d})$ than the dam re-mated immediately after parturition $(20.31 \mathrm{~g} / \mathrm{d})$, this may be due to utilization of nutrients by dam both for milk production and embryo development, when dam re-mated immediately after parturition. Fraga et al. (1989) reported that does re-mated 1 day after parturition showed a lower milk yield than those re-mated 8 days later, the decrease being more apparent at the end of lactation.

\section{Conclusion}

Conception rate, gestation length, litter size at birth and weaning, litter weight at weaning, does weight at mating, kidding and weaning and kits mortality were not significantly affected by the postpartum re-mating interval. However, higher growth rate, litter weight at birth and milk yield are obtained while rabbit does are re-mated at 10 days post partum.

\section{References}

Awojobi HA, Odutayo OO, Awojobi EA (2005). Knowledge of reproduction management practices among rabbit farmers. African Journal of Livestock Extension, 4: 78-83.

Cheeke PR (1983). Summary of a United Kingdom Rabbit Research Conference. Journal of Applied Rabbit Ressearch, 6: 86-87.

FAO (1996). World Food Summit Plan of Action. Food and Agriculture Organization of the United Nations, Rome, Italy.

Fraga MJ, Lorente M, Carabaño RM, Blas JC (1989). Effects of diet and of remating interval on milk production and milk composition of the doe rabbit. Animal Production, 48: 459-466.

Harkness JE (1988). Rabbit behaviour as related to environmental stress. Journal of Applied Rabbit Ressearch, 11: 227-236.

Harris DJ, Cheeke PR, Patton NM (1982). Effect of diet, light and breeding schedule on rabbit performance. Journal of Applied Rabbit Research. 5: 33-37.

Iyeghe-Erakpotobor GT, Oyedipe EO, Eduvie LO, Ogwu D (2005). Effect of rebreeding interval on reproductive performance and body weight changes of does during pregnancy. Nigerian Journal of Animal Production, 32: 142-152.

Leach IB, Barret JC (1984). Rabbit skins: problem and prospect for less developed countries. Journal of Applied Rabbit Research. 7: 91.

Lebas F, Coudert P, Rouvier R, Rochambeay H (1986). The rabbit husbandry, health and production. Anim. prod. and health series, FAO, Rome. P. 28-36.

Martin MMS, Donal R (1976). Comparaison d'un rythme de reproduction intensif et d'un rythme semi-intensif chez la lapine. Premier Congrës International Cunicole. Dijon, France. P. 75. 


\section{Effect of re-mating intervals on performance of rabbit}

McNitt JI, Patton NM, Cheeke PR, Lukefahr SD (1996). Rabbit production, 7th Edition, Inter State Publishers Inc. Danville, Illinois. P. 45.

Mendez J, De Blas J C, Fraga MJ (1986). The effect of diet and remating interval after parturition on the reproductive performance of the commercial doe rabbit. J ournal of Animal Science, 62: 1624-1634.

Nicodemus N, Gutierrez I, Garcia J, Carabano R, Deblas C (2002). The effect of re-mating interval and weaning age on the reproductive performance of rabbit does. Animal Research, 51: 517-523.

Oguike MA, Okocha NL (2008). Reproductive performance of rabbits re-mated at different intervals post-partum. African Journal of Agricultural Research, 3: 412415.
Owen JE (1981). Rabbit meat for the developing countries. World Animal Review, 39: 2-11.

Partridge GG, Allan JJ, Findlay M, Corrigall W (1984). The effects of reducing the remating interval after parturition on the reproductive performance of the commercial doe rabbit. Animal Production, 39: 465-472.

Rafel O (2001). La producción cunícola en España, in: Jornadas Profesionales de unicultura, Caleya, Spain, 1: 1-1.3.

Smith OB, Somade B (1994). Interaction between nutrition and reproduction in farm animals. In Animal Reproduction proceedings of a Regional Seminar held by the Int. Found. Science (IFS) Niamey, Niger, 17: 7-26. 